\title{
AGE-RAGE Axis in the Pathophysiology of Chronic Lower Limb Ischemia and a Novel Strategy for Its Treatment
}

\author{
Kailash Prasad, MBBS (Hons), MD, PhD, DSC, FRCPC, FACC, FIACS, FICA ${ }^{1}$ Kalpana K. Bhanumathy, PhD ${ }^{2}$ \\ ${ }^{1}$ Department of Physiology (APP), College of Medicine, University of \\ Saskatchewan, Saskatoon, SK, Canada \\ 2 Division of Oncology, Cancer Cluster Unit, College of Medicine, \\ University of Saskatchewan, Saskatoon, SK, Canada \\ Address for correspondence Kailash Prasad, MBBS (Hons), MD, PhD, \\ DSc, Department of Physiology (APP), College of Medicine, University \\ of Saskatoon, 107 Wiggins Road, Saskatoon, SK, S7N 5E5, Canada \\ (e-mail: k.prasad@usask.ca).
}

Int J Angiol 2020;29:156-167.

\begin{abstract}
Keywords

- advanced glycation end products (AGE)

- cell receptor for AGE

- soluble receptor for AGE

- AGE-RAGE stress

- chronic lower limb ischemia

- atherosclerosis

- treatment of chronic lower limb ischemia

This review focuses on the role of advanced glycation end products (AGEs) and its cell receptor (RAGE) and soluble receptor (sRAGE) in the pathogenesis of chronic lower limb ischemia (CLLI) and its treatment. CLLI is associated with atherosclerosis in lower limb arteries. AGE-RAGE axis which comprises of AGE, RAGE, and sRAGE has been implicated in atherosclerosis and restenosis. It may be involved in atherosclerosis of lower limb resulting in CLLI. Serum and tissue levels of AGE, and expression of RAGE are elevated, and the serum levels of sRAGE are decreased in CLLI. It is known that AGE, and AGE-RAGE interaction increase the generation of various atherogenic factors including reactive oxygen species, nuclear factor-kappa B, cell adhesion molecules, cytokines, monocyte chemoattractant protein-1, granulocyte macrophage-colony stimulating factor, and growth factors. sRAGE acts as antiatherogenic factor because it reduces the generation of AGE-RAGE-induced atherogenic factors. Treatment of CLLI should be targeted at lowering AGE levels through reduction of dietary intake of AGE, prevention of AGE formation and degradation of AGE, suppression of RAGE expression, blockade of AGE-RAGE binding, elevation of sRAGE by upregulating sRAGE expression, and exogenous administration of sRAGE, and use of antioxidants. In conclusion, AGE-RAGE stress defined as a shift in the balance between stressors (AGE, RAGE) and antistressor (sRAGE) in favor of stressors, initiates the development of atherosclerosis resulting in CLLI. Treatment modalities would include reduction of AGE levels and RAGE expression, RAGE blocker, elevation of sRAGE, and antioxidants for prevention, regression, and slowing of progression of CLLI.
\end{abstract}

Lower limb ischemia is of two types: acute and chronic. Acute lower limb ischemia is mostly due to sudden obstruction of lower limb arteries because of embolus or thrombosis. ${ }^{1}$ Very rarely aortic dissection and thrombosis of popliteal artery aneurysm may cause acute lower limb ischemia. Chronic lower limb ischemia (CLLI), a slowly progressive disease due to obliteration of arteries in the lower limb, is classified as mild, moderate, and critical. ${ }^{2}$ Mild CLLI is asymptomatic. Moderate CLLI causes intermittent claudica- tion, while critical CLLI is characterized by pain at rest and may culminate into nonhealing chronic leg ulcer and gangrene. Critical lower limb ischemia (CLI) is caused by atherosclerosis and the risk factors for CLI are similar to those of atherosclerosis, such as diabetes, dyslipidemia, smoking, hypertension, obesity, and infection. ${ }^{3}$

Prevalence of CLLI rises with age. It is uncommon before the age of 50 years but rises to $20 \%$ at the age of 80 years. ${ }^{4}$ It is estimated that more than 200 million people suffer from CLLI published online May 14,2020
Copyright $\odot 2020$ by Thieme Medical Publishers, Inc., 333 Seventh Avenue, New York, NY 10001, USA. Tel: +1(212) 760-0888.
DOI https://doi.org/ 10.1055/s-0040-1710045. ISSN 1061-1711. 
worldwide. ${ }^{5}$ The overall prevalence and incidence of CLLI in elderly people in U.S. are 0.23 and $0.20 \%$, respectively, and increase with diabetes and aging, and are higher in male than female. ${ }^{6}$ It is also reported that in diabetics the risk of critical lower limb ischemia is increased by 7.6-fold. The incidence of CLLI in black Americans is $0.41 \%$ while that in white Americans it is $0.18 \%$.

Advanced glycation end products (AGEs) and its cellbound receptor RAGE (receptor for AGE) and soluble receptor for AGE (sRAGE) have been implicated in carotid artery de-endothelialization-induced neointima expansion in wild-type mice, ${ }^{7,8}$ streptozocin-induced diabetes accelerated atherosclerosis in apolipoprotein $\mathrm{E}$ (apoE)-deficient mice, ${ }^{9}$ coronary artery disease (CAD), ${ }^{10}$ and restenosis following percutaneous coronary intervention (PCI). ${ }^{11}$ AGERAGE axis comprise of AGE, RAGE, and sRAGE. Possibilities exist that AGE-RAGE axis is involved in the pathogenesis of atherosclerosis in the arteries supplying the lower limb resulting in CLLI. If AGE-RAGE is involved in the development of chronic limb ischemia, then the levels of AGE in artery and serum, and expression of RAGE in artery will be elevated, and serum levels of SRAGE will be reduced in patients with chronic limb ischemia. Understanding the role of AGERAGE axis in atherosclerosis in CLLI a novel strategy can be developed for the prevention, slowing of progression, and regression of CLLI. This article gives a brief review of AGERAGE axis, serum levels of AGE and sRAGE, and tissue levels of RAGE expression, AGE-RAGE interaction, mechanisms by which AGE-RAGE axis induces atherosclerosis, and targeting AGE-RAGE axis for the treatment of CLLI.

\section{AGE-RAGE Axis}

AGEs are heterogeneous groups of irreversible adducts formed from nonenzymatic interaction of amino groups of proteins, lipids, and nucleic acids with reducing monosaccharides such as glucose, fructose, and glyceraldehyde. ${ }^{12,13}$ AGE interacts with RAGE, sRAGE, cRAGE, and esRAGE. RAGE is cell-bound receptor for AGE. There are two isoforms of RAGE: cleaved RAGE (cRAGE) which is proteolytically cleaved from full-length RAGE, ${ }^{14}$ and endogenous secretory RAGE (esRAGE) which is produced from splicing of fulllength RAGE messenger ribonucleic acid (mRNA). ${ }^{15}$ sRAGE is composed of both cRAGE and esRAGE, and AGE interacts with its cell receptor (RAGE) to produce reactive oxygen species (ROS) through activation of nicotinamide adenine dinucleotide phosphate (NADPH) oxidase ${ }^{16}$ which activates nuclear factor-kappa B (NF- $k$ B $).{ }^{17}$ Activated NF- $k$ B activates numerous genes like tumor necrosis factor- $\alpha$ (TNF- $\alpha$ ), interleukin (IL)-1, IL-2, IL-6, IL-8, and IL-9. ${ }^{18,19}$ Proinflammatory cytokines upregulates NADPH oxidase ${ }^{20}$ and increase the generation of ROS. ${ }^{21}$ SRAGE acts as a decoy for RAGE by binding with RAGE ligands. ${ }^{22}$ Binding of SRAGE with ligands does not activate intracellular signaling. SRAGE also is a competitive inhibitor of ligand-RAGE interaction. ${ }^{23}$ AGERAGE stress has been defined as a shift in the balance between stressors (AGE, RAGE) and antistressors (sRAGE) in favor of stressors. ${ }^{24}$

\section{Serum and Tissue Levels of AGE in Chronic Lower Limb Ischemia}

The levels of AGE have been investigated in both animals and humans.

\begin{abstract}
Animals
AGE levels were elevated in blood vessels of femoral artery ligation-induced ischemic lower limb ischemia both in diabetic and nondiabetic mice. ${ }^{25}$ Tamarat et $\mathrm{al}^{26}$ have reported that plasma levels of AGE are markedly elevated in lower limb ischemia due to femoral artery ligation in streptozotocin-induced diabetic mice.
\end{abstract}

\section{Humans}

Skin autofluorescence (SAF) is a noninvasive measurement of levels of AGE in skin. ${ }^{27}$ SAF levels are elevated in patients with peripheral artery disease (PAD). ${ }^{28}$ SAF is an independent predictor of amputation of critical limb ischemia and is associated with 5-year mortality in patients with PAD. ${ }^{29}$ It has been reported that SAF is elevated in patients with carotid artery stenosis as compared with control, and the levels of SAF was greater in patients of carotid stenosis with peripheral artery occlusive disease than in patients with carotid artery stenosis alone..$^{30} \mathrm{Nin}$ et $\mathrm{al}^{31}$ in a 12 -year follow-up study have reported that the levels of $\mathrm{N}(6)$-carboxymethyl-lysine (CML), $\mathrm{N}$ (6)-carboxyethyl-lysine (CEL), and pentosidine are elevated in type 1 diabetes with cardiovascular complications including amputation because of lower limb ischemia and vascular surgery for peripheral atherosclerotic disease. These investigators also reported that the elevated levels of AGEs were associated with incidental fatal and nonfatal cardiovascular diseases and all-cause mortality independent of traditional cardiovascular risk factors. Plasma levels of AGEs and pentosidine are elevated in type 2 diabetic patients with CLLI and were inversely associated with ankle-brachial index. ${ }^{32}$ Plasma levels of AGE were elevated in patients with peripheral arterial disease. ${ }^{33}$ Prasad et $\mathrm{al}^{34}$ measured the serum levels of total AGEs (CML, CEL, methylglyoxal dimer, and pyrilamine) using AGE enzyme-linked immunosorbent assay (ELISA) kit, and CML using anti-CML specific monoclonal antibody-based ELISA kit in 16 patients with critical limb ischemia and 26 patients with lifestyle-limiting claudication. They observed that both the total AGE and CML levels were elevated in critical limb ischemia; however, the correlation was greater with total AGE than with CML. In summary, serum and tissue levels of AGEs are elevated in patients with CLLI.

\section{Expression of RAGE in Vessels of Chronic Lower Limb Ischemia}

Expression of RAGE in ischemic lower limb has been reported both in animals and humans.

\section{Animals}

Using single-photon emission computerized tomography/ computed tomography scan, ex vivo gamma counting and immunohistopathology, Tekabe et $\mathrm{al}^{35}$ have shown that the 
expression of RAGE were higher in ischemic limb of diabetic and nondiabetic mice than in nonischemic diabetic and nondiabetic mice. Lower limb ischemia in the mice was produced by ligating left femoral artery. Streptozotocin was used to produce diabetes.

\section{Humans}

Ritthaler et $\mathrm{al}^{36}$ have observed that RAGE expression in endothelial cells was elevated in patients with PAD with or without diabetes compared with healthy subjects. All selected patients were in stages IIb-IV according to Fontaine criteria for peripheral occlusive vascular disease. The control subjects had no diabetes or peripheral vascular occlusive disease. Malmstedt et $\mathrm{al}^{33}$ reported that RAGE expression was observed in vein used for bypass in patients with peripheral arterial disease.

\section{Serum/Plasma Levels of sRAGE in Chronic Lower Limb Ischemia}

There are very few papers available in literature on the serum/plasma levels of sRAGE in CLLI in animals and humans.

\section{Animals}

Kim et $\mathrm{al}^{37}$ have shown that blood flow ratio of ischemic/control limb in hindlimb ischemia model of mice was significantly reduced in diabetic mice compared with nondiabetic mice postoperatively. However, the blood flow ratio of ischemic/control was significantly greater in mice treated with sRAGE compared with control group postoperatively. They also showed that the capillary density was reduced in ischemic limb of diabetic mice compared with ischemic limb of nondiabetic mice. However, the capillary density was greater in mice treated with sRAGE compared with untreated diabetic mice. These data suggest that sRAGE levels may be lower in ischemic lower limb.

\section{Humans}

Falcone et $\mathrm{al}^{38}$ measured the plasma levels of sRAGE in CAD patients with and without PAD (chronic limb ischemia). The patients with PAD had ankle-brachial index of $<0.9$ and were in stage of IIb and stage III according to Fontaine classification. These authors reported that plasma sRAGE levels were $48 \%$ lower in CAD patients with or without PAD as compared with controls. sRAGE levels were $19.7 \%$ lower in CAD patients with PAD as compared with CAD patients without PAD. These values suggest that plasma levels of sRAGE are lower in patients with PAD as compared with controls.

In summary, serum/plasma levels of AGE and expression of RAGE are elevated while plasma levels of sRAGE are reduced in patients with CLLI.

\section{Role of AGE-RAGE Axis in the Development of Atherosclerosis}

AGE could induce development of atherosclerosis through nonreceptor and receptor-dependent mechanisms.

\section{Nonreceptor-Dependent Mechanism of AGE in Development of Atherosclerosis}

There are various pharmacological effects of AGE in inducing atherosclerosis. AGE modifies apoB100 which makes lowdensity lipoprotein (LDL) cholesterol more atherogenic. ${ }^{39}$ AGE increases synthesis of extracellular matrix, ${ }^{40}$ traps endothelial LDL, ${ }^{41}$ and cross-binds with collagen. ${ }^{42}$ Glycation of apoB and phospholipid component of LDL alters LDL clearance and increases the susceptibility of LDL oxidation. ${ }^{43,44}$ AGE increases susceptibility of LDL to oxidation. ${ }^{45}$ AGE decreases the production of nitric oxide (NO). ${ }^{46}$ Oxidized LDL (Ox-LDL) decreases the production of NO through reduction of NO-synthase (NOS). ${ }^{47}$ It has been reported that AGE quenches NO. ${ }^{48}$ Matrix-bound AGE reduces NO production, ${ }^{49}$ decreases the half-life of NOS, ${ }^{50}$ quenches and inactivates $\mathrm{NO},{ }^{51}$ and inhibits the antiproliferative activity of $\mathrm{NO}^{52}$ AGE reduces NOS mRNA and protein resulting in reduction in NO levels. ${ }^{53}$ Matrix-bound AGE also increases the expression of endothelin- $1^{54}$ which has been implicated in the development of atherosclerosis. ${ }^{40}$ Glycation of LDL decreases its recognition by LDL receptors. ${ }^{55}$ Glycated LDL increases the smooth muscle cell proliferation and differentiation. ${ }^{56}$ AGE interferes reverse cholesterol transport ${ }^{57}$ which will increase the extracellular cholesterol. AGE increases accumulation of cholesterol and its esters in macrophages in vitro. ${ }^{58}$

\section{Receptor-Mediated Mechanism}

AGE interacts with RAGE to generate ROS through activation of NADPH oxidase. ${ }^{16}$ ROS then activates NF- $k$ B which in turn results in transcriptional activation of variety of inflammatory genes such as TNF- $\alpha$, TNF- $\beta$, IL-1, IL-6, IL-8, and interferongamma. ${ }^{18,59-61} \mathrm{NF}-k \mathrm{~B}$ induces gene for NADPH oxidase in polymorphonuclear leukocytes ${ }^{62}$ which would generate ROS. Interaction of AGE and RAGE enhances expression of intercellular adhesion molecule-1, vascular cell adhesion molecule-1 (VCAM-1), and E-selectin through NF- $k$ B. ${ }^{60}$ In apo-deficient mice, streptozotocin-induced diabetes was associated with increased expression of VCAM- 1 and tissue factor. ${ }^{63}$ AGE upregulates expression of monocyte chemoattractant protein-1 (MCP-1) mRNA in mesangial cells. ${ }^{64}$ AGE increases expression of MCP-1 and vascular endothelial growth factor in human-cultured mesangial cells. ${ }^{65}$ AGE induces expression of MCP-1 in podocytes through activation of RAGE and generation of intracellular ROS. ${ }^{66}$ AGE increases the expression and secretion of granulocyte macrophage-colony stimulating factor (GM-CSF) by macrophages. ${ }^{67}$ Interaction of AGE with RAGE on mononuclear leukocytes produces phenotype of activated macrophages that promotes induction of insulin-like growth factor (IGF), IGF-1, and platelet-derived growth factor (PDGF). ${ }^{68,69}$ Binding of AGE with RAGE bearing mononuclear phagocytes enhances chemotaxis leading to mononuclear monocytes infiltration through intact endothelial surface. ${ }^{70,71}$ AGE-RAGE binding in smooth muscle cells enhances chemotactic migration, cellular proliferation, and production of fibrogen. ${ }^{72,73}$ AGE increases expression of transforming growth factor- $\beta$ (TGF- $\beta$ ) which is involved in extracellular matrix formation. ${ }^{74}$ It is to note that ROS is involved in expression of VCAMs through activation of NF- $k$ B. AGE-RAGE interaction 


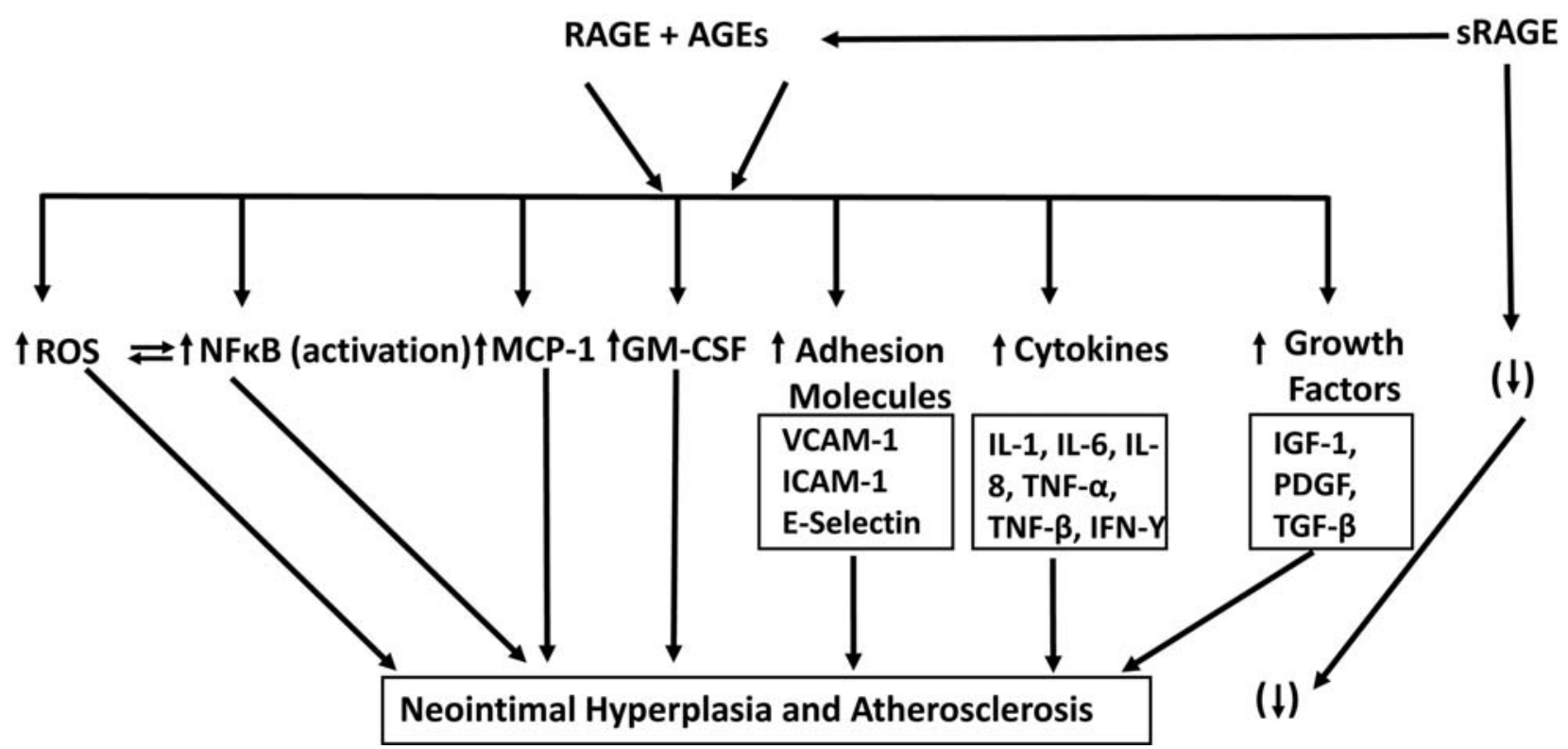

Fig. 1 Effects of interaction of AGE with RAGE and AGE with SRAGE on generation of atherogenic factors. AGE-RAGE interaction increase the generation of ROS (reactive oxygen species), NF-kB (nuclear factor-kappa B) activation, MCP-1 (monocyte chemoattractant protein-1), GM-CSF (granulocyte macrophage-colony stimulating factor), VCAM-1 (vascular cell adhesion molecule-1), ICAM-1 (intercellular adhesion molecule -1), E-selectin; IL (interleukin), TNF- $\alpha$ (tumor necrosis factor- $\alpha$ ), TNF- $\beta$, IFN- $\Upsilon$ (interferon-gamma), which are involved in the development of neointimal hyperplasia and atherosclerosis. Interaction of AGE with sRAGE reduces the amount of AGE to interact with RAGE leading to reduction in formation of atherogenic factors resulting in decreased development of neointimal hyperplasia and atherosclerosis. AGE, advanced glycation end products; RAGE, cell receptor for AGE; SRAGE, soluble receptor for AGE; PDGF, platelet-derived growth factor; IGF-1, insulin like growth factor- 1 ; TGF- $\beta$, transforming growth factor- $\beta ; . \uparrow$, increase; $\downarrow$, decrease.

decreases endothelial barrier function and hence increases permeability of endothelial cell layer. ${ }^{75,76}$ AGE also interacts with sRAGE and has protective effect against adverse effects of AGE-RAGE interaction. ${ }^{22,23}$ - Fig. 1 shows the receptor-mediated effects of AGE in the development of atherosclerosis. AGERAGE interaction produces atherosclerosis through generation of various chemicals while SRAGE prevent the development of atherosclerosis by reducing the formation of these chemicals.

\section{Mechanism of AGE-RAGE Axis-Induced Atherosclerosis}

The proposed mechanism of AGE-RAGE-induced atherosclerosis is depicted in - Fig. 2. It is based on oxidative hypothesis of atherosclerosis. ${ }^{75}$ The first step in the development of atherosclerosis is mild oxidation of LDL called minimally modified LDL (MM-LDL). MM-LDL is further oxidized to produce Ox-LDL. Monocytes adhere to endothelium and transmigrate into subendothelial space. ${ }^{76}$ Smooth muscle cells and endothelial cells exposed to MM-LDL produce MCP-1 which assist monocyte migration. Also, Ox-LDL directly enhances monocyte migration. Monocytes/macrophages express LDL receptor but the uptake of native LDL is not sufficient to produce foam cells. Ox-LDL is a ligand for scavenger receptor that is expressed when monocytes differentiate into tissue macrophages. Monocyte/macrophage differentiation is enhanced by release of monocyte-CSF from endothelial cells stimulated by MM-LDL. Tissue macrophage has receptors for Ox-LDL to produce foam cells, a major component of fatty streak. It is an early stage of atherosclerosis. Macrophages generate numerous growth regulating molecules. ${ }^{77}$ As mentioned above, AGE-RAGE interaction induces numerous growth factors (PDGF, IGF-1, TGF- $\beta$ ) (68-74 $^{6}$ which would increase smooth muscle proliferation and migration, and fibrous tissue formation. Fatty streaks develop into full-fledged atherosclerosis which is associated with smooth muscle cell and lipid accumulation, necrotic core, and formation of fibrous cap. ${ }^{72,73,77}$

\section{ROS and Atherosclerosis}

Oxygen radicals have been implicated in the development of atherosclerosis. ${ }^{78,79}$ ROS generated by interaction of AGE with RAGE, therefore, would induce atherosclerosis.

\section{Treatment Modalities}

Considering the role of AGE-RAGE axis in the pathophysiology of atherosclerosis and hence CLLI, the treatment of CLLI should be directed toward reduction in levels of AGE, ROS, and RAGE, blocking of RAGE binding with AGE, degradation of AGE in vivo, elevation of sRAGE levels, and antioxidant (-Fig. 3). Targeting these pathways would prevent, regress, or slow the progression of CLLI. A brief description of these targets is being described here. 


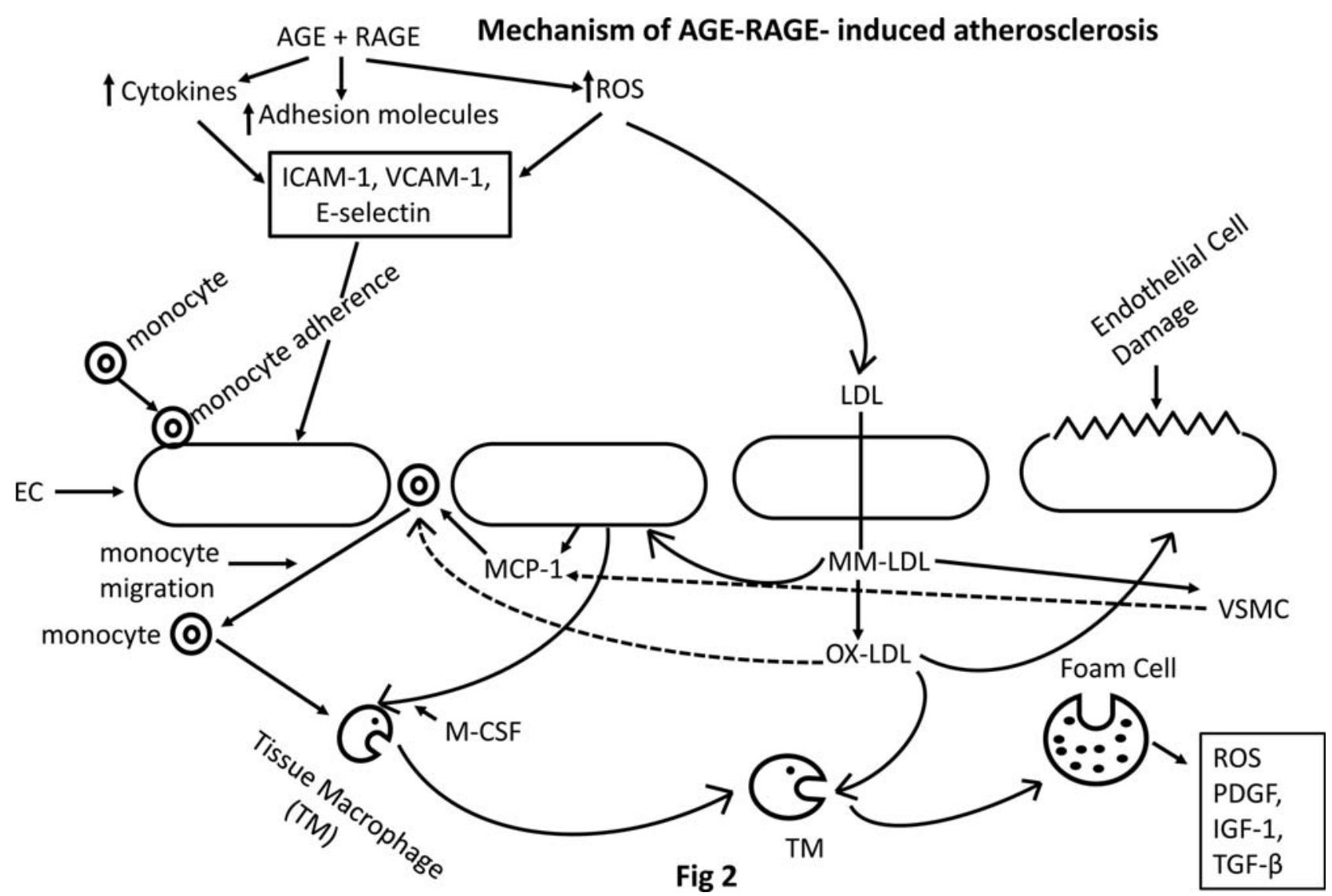

Fig. 2 Mechanism of AGE-RAGE-induced atherosclerosis. AGE, advanced glycation end products; RAGE, cell receptor for AGE; ROS, reactive oxygen species; ICAM-1, intercellular adhesion molecule-1; VCAM-1, vascular cell adhesion mplecule-1; LDL, low -density lipoprotein; MM-LDL, minimally modified LDL; Ox-LDL, oxidized-LDL; MCP-1, monocyte chemoattractant protein-1; MC-SF, monocyte colony stimulating factor; VSMC, vascular smooth muscle cell; EC, endothelial cell; PDGF, platelet-derived growth factor; TGF- $\beta$, transforming growth factor- $\beta$; IL, interleukin; TNF$\alpha$, tumor necrosis factor- $\alpha$; IFN- $\Upsilon$, interferon-gamma; TM, tissue macrophage; EC, endothelial cell; VSMC, vascular smooth muscle cell; TM, tissue macrophage; $\uparrow$, increase.

\section{Potential treatment targets for CLLI}

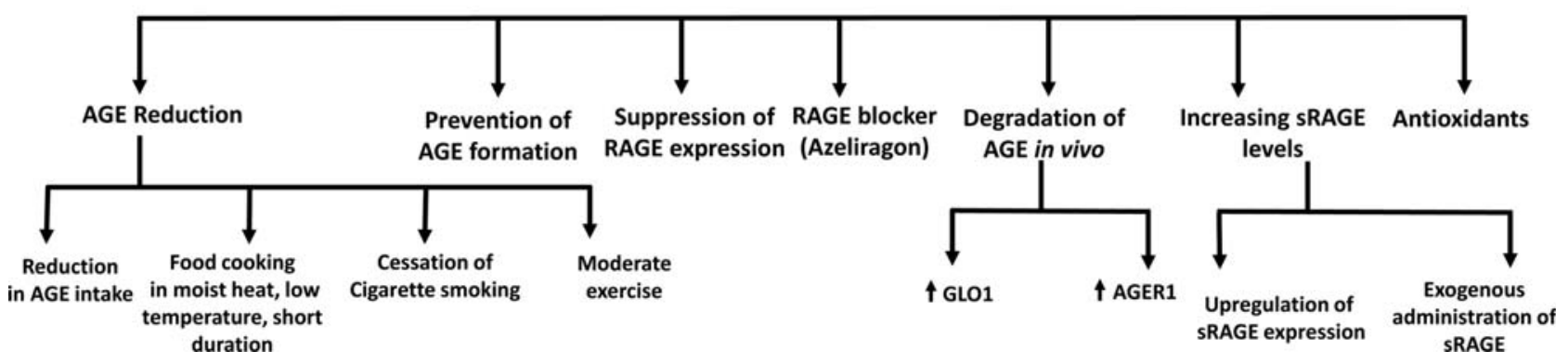

Fig. 3 Potential treatment targets for chronic lower limb ischemia (CLLI). AGE, advanced glycation end products; RAGE, receptor for AGE; SRAGE, soluble receptor for AGE; GLO1, glyoxalase 1; AGER1, advanced glycation end products receptor 1.

\section{AGE Reduction}

Reduction of AGE levels in the body can be achieved by reduction in dietary intake of AGEs, prevention of AGE formation, and degradation of AGE in the body.

\section{AGE Intake Reduction}

There are certain diets which are rich in AGE content (red meat, cheese, cream, animal fat, sweetened pastry). ${ }^{80}$ Butter, cheese, cream, margarine, and mayonnaise contain high quantity of AGE than oil and nuts. ${ }^{81}$ Beef has highest amount of AGE followed by poultry, pork, fish, and eggs in the meat class. ${ }^{81}$ Grains, legumes, breads, vegetables, fruits, and milk contains lowest amount of AGE. ${ }^{81}$ Fat-free milk has lower amount of AGE compared with whole milk. ${ }^{81}$ Consumption of food containing high amount of AGE should be reduced in patients with CLLI. Patients should be advised to consume less sugar because sugars participate in generation of AGEs. ${ }^{12,13}$ It has been reported that serum levels of AGE is 
markedly reduced in healthy or diabetic individual with short-term consumption of low AGE containing diet. ${ }^{82}$

\section{Food Cooking}

Cooking at high temperature in dry heat (frying, broiling, grilling, roasting) increases AGE formation more than cooking in moist heat (poaching, stewing, steaming, and boiling). ${ }^{83}$ Duration of cooking also affects the formation of AGEs. The formation of AGEs is markedly reduced when cooking at low temperature in moist heat for short duration. ${ }^{81}$

\section{Other AGE-Lowering Maneuvers}

Cigarette smoking increases the serum levels of AGEs, ${ }^{83}$ and hence the patient should be advised to stop cigarette smoking. AGE levels are reduced by 41 to $60 \%$ with long runs in untrained and trained subjects. ${ }^{84}$ Reduction in serum levels of AGEs is greater with regular moderate exercise than irregular severe exercise. ${ }^{85}$ Serum levels of AGE are reduced with Tai chi exercise of moderate intensity. ${ }^{86}$ Patients should be advised to do regular exercise of moderate intensity.

\section{Prevention of AGE Formation}

Consumption of acidic ingredients (lemon juice, vinegar) ${ }^{87}$ and pomegranate and its phenolic components ${ }^{88}$ should be advocated because they prevent AGE formation. Some vitamins such as benfotiamine, ${ }^{89}$ pyridoxine, ${ }^{90}$ vitamin $C,{ }^{91}$ vitamin $D,{ }^{92}$ and vitamin $\mathrm{E}^{93}$ prevent the formation of AGEs. Carnosine, an antioxidant from meat, inhibits AGE formation. ${ }^{94} \mathrm{D}$-carnosine has been reported to prevent development of atherosclerosis in diabetic mice. ${ }^{95,96}$ Linolenic acid prevents the formation of AGEs. ${ }^{97}$ Aminoguanidine inhibits AGE formation. ${ }^{98}$ Clinical trials with aminoguanidine have been terminated due to its undesirable side effects. ${ }^{99}$ Alpha-lipoic acid, ${ }^{100}$ aspirin, ${ }^{101}$ metformin, ${ }^{102}$ pentoxifylline, ${ }^{103}$ resveratrol, ${ }^{104}$ and curcu$\min ^{105}$ are potential inhibitors of AGE formation.

\section{Suppression of RAGE Expressions and RAGE Blockers}

Statins (simvastatin, atorvastatin), ${ }^{106,107}$ angiotensin-II receptor blockers (candesartan, telmisartan), ${ }^{108,109}$ calcium channel blocker (nifedipine), ${ }^{110}$ antidiabetic agents (pioglitazone, rosiglitazone), ${ }^{111}$ and curcumin ${ }^{112}$ downregulate the expression of RAGE. Azeliragon (TTP488) inhibits interaction of RAGE with AGE and other RAGE ligands. ${ }^{13}$ RAGE receptor blockers have been described in detail by Bongarzone et al. ${ }^{114}$ Preclinical studies in animal model of Alzheimer's disease have shown that azeliragon decreases plaque deposition and slow cognitive decline. ${ }^{115}$ Azeliragon in low doses improves cognitive function in patients with Alzheimer's disease. ${ }^{113}$ Azeliragon treatment in mild to moderate Alzheimer's disease was found to be effective but phase 2 clinical trial was stopped because of adverse side effects. The search for RAGE blocker is on. ${ }^{116}$

\section{Degradation of AGE In Vivo}

Increasing Expression and Activity of Endogenous Glyoxalase 1

Glyoxalase 1 (GLO1) degrades AGE through degrading reactive dicarbonyls prior to formation of AGE. ${ }^{117}$ Overexpres- sion of GLO1 would be helpful in reducing the levels AGE. It has been reported that combined use of transresveratrol found in grapes and hesperetin found in orange increased the expression and activity of GLO1 in a placebo-controlled crossover clinical trial. ${ }^{118}$ It was also reported that overexpression of GLo1 in lens and retinal capillary pericytes protected against hyperglycemia-induced protein modification $^{119}$ and apoptosis. ${ }^{120}$

\section{Increasing Expression and Activity of Endogenous Advanced Glycation End Products Receptor 1}

Advanced glycation end products receptor 1 (AGER1) degrades AGE intracellularly and is a blocker of AGE-RAGEmediated formation of ROS and proinflammatory cytokines. ${ }^{121,122}$ There is no specific drug which can increase the expression of AGER1. AGER1 counteracts AGE-induced oxidative stress through inhibition of RAGE signaling. ${ }^{121,122}$ Since AGER1 and RAGE competes for with AGE, low concentration of AGER1 would increase the binding of AGE with RAGE, resulting in increased oxidative stress and proinflammatory cytokines. AGER1 is an AGE receptor. ${ }^{123}$ Reduction in AGER1 expression is associated with elevated levels of SRAGE. ${ }^{124}$ AGER1 is positively correlated with sRAGE in complicated diabetes. ${ }^{124}$ The above data suggests that AGER1 may serve as a future target for treatment of CLLI.

\section{Increasing the Levels of SRAGE}

Levels of SRAGE could be increased in two ways: upregulation of expression of SRAGE and exogenous administration of SRAGE.

\section{Upregulation of sRAGE Expression}

Statins such as pitavastatin and pravastatin increased the serum levels of sRAGE and reduced the vascular remodeling and atheroma in patients with CAD. ${ }^{125}$ sRAGE levels are elevated in serum of patients with type 2 diabetes with atorvasttin. ${ }^{126}$ Other statins (atorvastatin, fluvastatin, lovastatin) increased the sRAGE levels in isolated cell culture. ${ }^{127}$

Angiotensin-converting enzyme inhibitors such as ramipril and perindopril increase the serum levels of sRAGE. It has been shown that ramipril increased the serum levels of sRAGE in rat, ${ }^{128}$ and perindopril increased the serum levels sRAGE in type 1 diabetic patients. ${ }^{128}$ Rosiglitazone ${ }^{129}$ an antidiabetic drug elevates the serum levels of sRAGE in type 2 diabetic patients. Serum levels of sRAGE are elevated in women with polycystic ovarian syndrome with rosiglitazone. ${ }^{130}$

\section{Exogenous Administration of sRAGE}

Animal studies suggest that AGE-RAGE axis is involved in the development of atherosclerosis. It has been reported that AGE and RAGE levels are elevated in the wall of carotid artery in Zucker diabetic rats as compared with euglycemic control rats. ${ }^{7}$ These authors also showed that balloon injury in carotid artery of these rats further increased the levels of AGE and RAGE in the carotid artery associated with neointimal hyperplasia. Administration of sRAGE before and up to 21 days after balloon injury significantly reduced the neointimal growth. Similarly, other investigators ${ }^{8}$ showed 
that arterial de-endothelialization in wild-type mice increased the levels of AGE and RAGE in the injured artery and this was associated with expansion of neointima. Administration of sRAGE reduced the neointimal expansion and decreased smooth muscle cell proliferation and migration, and extracellular matrix proteins expression. Administration of sRAGE has been demonstrated to completely suppress atherosclerosis in diabetic apoE-deficient mice and this effect was independent of hyperglycemia and lipid concentration. ${ }^{131}$ sRAGE has been shown to protect ischemic stroke in animal model. ${ }^{132}$ The above data suggest that sRAGE could be effective in the prevention and treatment of atherosclerosis. However, no clinical trial with SRAGE has been made in human atherosclerosis as yet.

\section{Antioxidants}

As mentioned earlier, AGE-RAGE interaction produces ROS, ${ }^{16,62}$ which have been implicated in the development of atherosclerosis. ${ }^{78,133-135}$ Considering that antioxidants may be helpful in the treatment of CLLI, there are quite a few antioxidants that can be used. Antioxidants have been shown to reduce the development of atherosclerosis. ${ }^{136,137}$ Prasad and Kalra ${ }^{138}$ have reported that vitamin E significantly prevented the development of hypercholesterolemia-induced atherosclerosis in rabbits. Hypercholesterolemia increases generation of ROS through various mechanisms. ${ }^{138}$ Longterm (18 months) use of vitamin E (50 IU in diet) with low fat/cholesterol diet reduced atherosclerosis in $\mathrm{Ldll}^{-1-}$ mice. ${ }^{139}$ Clinical trials in humans showed some positive benefits. ${ }^{140}$ Meta-analysis did not show evidence of antiatherosclerotic effects of vitamin E. ${ }^{141}$ Failure of antioxidant strategies may be due to inappropriate doses, lack of combination of antioxidants, application of antioxidants in very advanced atherosclerosis, and frequency of drug administration. Vitamin alone may not be effective because when vitamin E scavenges ROS, it gets converted into tocopheryl radical which is harmful. Vitamin $C$ regenerates vitamin $\mathrm{E}$ from tocopheryl. ${ }^{142}$ Combination of vitamin $\mathrm{E}$ with vitamin $\mathrm{C}$ would be helpful. Vitamin $\mathrm{C}$ is a water-soluble antioxidant. ${ }^{143}$

Coenzyme $\mathrm{Q}^{10}$ is a lipophilic antioxidant, scavenges peroxyl radicals, and has antiatherogenic effects. ${ }^{144}$ Probucol is a lipidsoluble antioxidant ${ }^{143}$ and has antiatherogenic effect. ${ }^{145}$ Prasad et al $^{135}$ have reported that probucol ameliorated the development of atherosclerosis in hypercholesterolemic rabbit. It has been shown to reduce restenosis following PCI. ${ }^{146} \mathrm{It}$ inhibits smooth muscle cell proliferation and cell adhesion molecule expression on endothelial cells. ${ }^{143}$ There is a synthetic antioxidant BO-653n which is an analogue of $\alpha$-tocopherol and inhibits development of athertosclerosis. ${ }^{147}$ It reduces $\alpha$-tocopheroxyl radical and inhibits LDL oxidation in the intimal area. ${ }^{148}$ Other antioxidants such as garlic ${ }^{149}$ and secoisolariciresinol diglucoside have been reported to prevent hypercholesterolemic atherosclerosis. ${ }^{134}$

\section{Perspectives}

CLLI is due to atherosclerosis in the arteries of lower limb. As described earlier in this article, AGE-RAGE axis plays a role in the development of atherosclerosis in numerous ways. First,
AGE and its interaction with RAGE reduces the levels of NO which is known to protect atherosclerosis through vasodilation, and inhibition of inflammatory mediators, platelet aggregation, and platelet activation. ${ }^{150-152}$ Second, glycated lipoprotein B100 enhances the atherogenic activity of LDL. ${ }^{39}$ Third, AGE-RAGE interaction decreases the reverse cholesterol transport. ${ }^{153}$ Fourth, AGE and its interaction with RAGE produce ROS, NF- $k$ B, cytokines, adhesion molecules, MCP-1, GM-CSF, and growth factors which are involved in the development of atherosclerosis and has been described in detail in the previous section of this article. Besides these, it is to note that VCAM-1 induces activation of NADPH oxidase in the endothelium ${ }^{154}$ which would increase the ROS levels and hence development of atherosclerosis.

AGE, RAGE, and sRAGE may play an important role in the development of atherosclerosis and hence CLLI. As described earlier in this article, plasma and skin ${ }^{25-34}$ levels of AGE and RAGE expression in tissue ${ }^{33-35}$ are elevated while the serum levels of $\mathrm{SRAGE}^{37,38}$ are reduced in patients with CLLI. In addition, AGE is present in the atherosclerotic plaque of diabetic patients. ${ }^{155}$ SRAGE is antiatherogenic because it competes with RAGE for binding with AGE. Also, it interacts with AGE before RAGE can interact with AGE. ${ }^{156}$ Thus, low sRAGE levels in patients with CLLI will bind with small amount of AGE and hence leaving more AGE available to interact with RAGE leading to development of atherosclerosis. Low levels of SRAGE is, therefore, atherogenic. It is known that atherosclerosis develops in diabetic patients in spite of high levels of sRAGE. ${ }^{157,158}$ One would have expected that high levels of sRAGE would have protected the development of atherosclerosis in diabetic patients but it did not do so. The reason could be that elevation of AGE levels is more than the elevation of sRAGE in diabetics. Hence, measurement of AGE and sRAGE in the same patient would be useful. Also, this will allow to assess the AGE-RAGE stress which is a ratio of AGE/sRAGE. ${ }^{24}$ AGE-RAGE stress is a risk factor for disease and high AGE-RAGE stress indicates the presence and severity of the disease.

Therapeutic intervention based on the etiology of CLLI, should include reduction in the levels of AGE, prevention of AGE formation, degradation of AGE in vivo, suppression of RAGE expression, RAGE blockers, and elevation of sRAGE that have been described in detail earlier in this article. It has been reported that consumption of low AGE diet for 2 months reduces the serum levels of AGE in mice. ${ }^{159}$ Reduction of AGE diet for a short duration reduced the serum levels of AGE in healthy and diabetic subjects. ${ }^{82}$ Stoppage of cigarette smoking will also reduce the serum levels of AGE. ${ }^{83}$ Exercise also reduces the levels of AGE in the serum. ${ }^{84,86,160,161}$ It has been reported that regular physical activity reduces AGE levels and diabetic complications. ${ }^{162}$ Unfortunately, no clinical trial has been conducted to examine the effectiveness of agents that reduce the formation of AGE or reduce the levels of AGE in reduction of atherosclerotic changes in patients with CLLI. Although some of the agents (benfotiamine, ${ }^{163}$ vitamin $\mathrm{E}^{138,164}$ ) have been shown to reduce the atherosclerotic changes in animal studies and humans. Combined use of vitamin $\mathrm{E}$ and vitamin $\mathrm{C}$ has been shown to slow down the progression of atherosclerosis in hypercholesterolemic subjects. ${ }^{165}$ Combination of vitamin $\mathrm{E}$ 
and vitamin $\mathrm{C}$ will be effective in reducing atherosclerosis in two ways: by scavenging ROS and by reducing the formation of AGE.

Enzymatic (GLO1 and GLO2) degradation and AGE receptor-mediated (AGER1 and AGER2) degradation of AGE would reduce the levels of AGE in the body. However, no such pharmaceuticals have been developed for use in patients. Attempt should be made by pharmaceutical companies to develop these degraders for use in humans.

There are drugs used in diabetic and hypertensive patients which suppress the expression of RAGE. Some of the patients with CLLI may already have been using these drugs and are getting the benefits. Azeliragon (a RAGE blocker) has been developed ${ }^{114}$ and has been shown to be effective in improving cognitive function in patients with Alzheimer's disease. ${ }^{113}$ May be this drug would work for patients with CLLI. A search for new RAGE blocker should be intensified.

The levels of sRAGE in blood should be elevated by increasing expression of sRAGE and by exogenous administration in patients with CLLI. The drugs (statins, angiotensin-converting enzyme inhibitors, antidiabetic drug, and rosiglitazone) elevate the sRAGE expression. Again some of the patients with CLLI may be using these drugs for other associated conditions, and taking advantage of this. Exogenous administration of SRAGE has been shown to be effective in preventing the development of atherosclerosis in animal studies. ${ }^{7,8,131,132}$ Exogenous administration of sRAGE should be tried in animal model of CLLI to see if it is effective in prevention, regression, and slowing of atherosclerosis. Also, recombinant sRAGE should be developed for use in humans, and tried in patients with CLLI.

These treatment modalities may not be fully effective in patients with CLLI because some other factors besides AGERAGE axis may also be involved in the pathogenesis of CLLI.

\section{Conclusion}

CLLI is due to atherosclerosis in the lower limb arteries. Elevated levels of AGE in serum/plasma, increased expression of RAGE in arteries, and reduced serum levels of sRAGE are involved the development of atherosclerosis through oxidation of LDL, reduction in NO, activation of NF- $k$ B, and increases in the levels of ROS, cell adhesion molecules, cytokines, MCP-1, GM-CSF, and growth factors. The treatment modalities (prevention, regression, and slowing of progression of atherosclerosis) of CLLI should include lowering of AGE consumption, prevention of AGE formation, increase in degradation of AGE in vivo, suppression of RAGE, RAGE blocker, upregulation of sRAGE expression, and exogenous administration of sRAGE.

\section{Disclosure \\ None.}

\section{Conflict of Interest}

None.

\section{References}

1 Creager MA, Kaufman JA, Conte MS. Clinical practice. Acute limb ischemia. N Engl J Med 2012;366(23):2198-2206

2 Varu VN, Hogg ME, Kibbe MR. Critical limb ischemia. J Vasc Surg 2010;51(01):230-241

3 Prasad K. Pathophysiology of Atherosclerosis. New York, NY: Springer Verlag; 2000:85-105

4 Allison MA, Ho E, Denenberg JO, et al. Ethnic-specific prevalence of peripheral arterial disease in the United States. Am J Prev Med 2007;32(04):328-333

5 Fowkes FG, Rudan D, Rudan I, et al. Comparison of global estimates of prevalence and risk factors for peripheral artery disease in 2000 and 2010: a systematic review and analysis. Lancet 2013;382(9901):1329-1340

6 Baser O, Verpillat P, Gabriel S, et al. Prevalence, incidence, and outcomes of critical limb ischemia in the US Medicare population. Vsc Dis Management 2013;10:E26-E36

7 Zhou Z, Wang K, Penn MS, et al. Receptor for AGE (RAGE) mediates neointimal formation in response to arterial injury. Circulation 2003;107(17):2238-2243

8 Sakaguchi T, Yan SF, Yan SD, et al. Central role of RAGE-dependent neointimal expansion in arterial restenosis. J Clin Invest 2003;111(07):959-972

9 Wendt TM, Bucciarelli LG, Lu X, et al. Accelerated atherosclerosis and vascular inflammation develop in apo-E null mice with type 2 diabetes. Circulation 2000;102(Suppl):II-231

10 McNair ED, Wells CR, Qureshi AM, et al. Low levels of soluble receptor for advanced glycation end products in non-ST elevation myocardial infarction patients. Int J Angiol 2009;18(04): 187-192

11 McNair ED, Wells CR, Mabood Qureshi A, et al. Soluble receptors for advanced glycation end products (SRAGE) as a predictor of restenosis following percutaneous coronary intervention. Clin Cardiol 2010;33(11):678-685

12 Bucala R, Cerami A. Advanced glycosylation: chemistry, biology, and implications for diabetes and aging. Adv Pharmacol 1992; 23:1-34

13 Thorpe SR, Baynes JW. Maillard reaction products in tissue proteins: new products and new perspectives. Amino Acids 2003;25(3-4):275-281

14 Tam XH, Shiu SW, Leng L, Bucala R, Betteridge DJ, Tan KC. Enhanced expression of receptor for advanced glycation endproducts is associated with low circulating soluble isoforms of the receptor in type 2 diabetes. Clin Sci (Lond) 2011;120(02): $81-89$

15 Yonekura H, Yamamoto Y, Sakurai S, et al. Novel splice variants of the receptor for advanced glycation end-products expressed in human vascular endothelial cells and pericytes, and their putative roles in diabetes-induced vascular injury. Biochem J 2003; 370(Pt 3):1097-1109

16 Wautier MP, Chappey O, Corda S, Stern DM, Schmidt AM, Wautier JL. Activation of NADPH oxidase by AGE links oxidant stress to altered gene expression via RAGE. Am J Physiol Endocrinol Metab 2001;280(05):E685-E694

17 Gloire G, Legrand-Poels S, Piette J. NF-kappaB activation by reactive oxygen species: fifteen years later. Biochem Pharmacol 2006;72(11):1493-1505

18 Reznikov LL, Waksman J, Azam T, et al. Effect of advanced glycation end products on endotoxin-induced TNF-alpha, IL1 beta and IL-8 in human peripheral blood mononuclear cells. Clin Nephrol 2004;61(05):324-336

19 Stassen M, Müller C, Arnold M, et al. IL-9 and IL-13 production by activated mast cells is strongly enhanced in the presence of lipopolysaccharide: NF-K B is decisively involved in the expression of IL-9. J Immunol 2001;166(07):4391-4398

20 Mohammed AM, Syeda K, Hadden T, Kowluru A. Upregulation of phagocyte-like NADPH oxidase by cytokines in pancreatic beta- 
cells: attenuation of oxidative and nitrosative stress by 2-bromopalmitate. Biochem Pharmacol 2013;85(01):109-114

21 Yang D, Elner SG, Bian ZM, Till GO, Petty HR, Elner VM. Proinflammatory cytokines increase reactive oxygen species through mitochondria and NADPH oxidase in cultured RPE cells. Exp Eye Res 2007;85(04):462-472

22 Prasad K, Tiwari S. Therapeutic interventions for advanced glycation-end products and its receptor- mediated cardiovascular disease. Curr Pharm Des 2017;23(06):937-943

23 Wendt T, Harja E, Bucciarelli L, et al. RAGE modulates vascular inflammation and atherosclerosis in a murine model of type 2 diabetes. Atherosclerosis 2006;185(01):70-77

24 Prasad K, Mishra M. AGE-RAGE stress, stressors, and antistressors in health and disease. Int J Angiol 2018;27(01):1-12

25 Hansen LM, Gupta D, Joseph G, Weiss D, Taylor WR. The receptor for advanced glycation end products impairs collateral formation in both diabetic and non-diabetic mice. Lab Invest 2017;97(01): $34-42$

26 Tamarat R, Silvestre JS, Huijberts M, et al. Blockade of advanced glycation end-product formation restores ischemia-induced angiogenesis in diabetic mice. Proc Natl Acad Sci U S A 2003;100 (14):8555-8560

27 Da Moura Semedo C, Webb M, Waller H, Khunti K, Davies M. Skin autofluorescence, a non-invasive marker of advanced glycation end products: clinical relevance and limitations. Postgrad Med J 2017;93(1099):289-294

28 de Vos LC, Noordzij MJ, Mulder DJ, et al. Skin autofluorescence as a measure of advanced glycation end products deposition is elevated in peripheral artery disease. Arterioscler Thromb Vasc Biol 2013;33(01):131-138

29 de Vos LC, Boersema J, Mulder DJ, Smit AJ, Zeebregts CJ, Lefrandt JD. Skin autofluorescence as a measure of advanced glycation end products deposition predicts 5-year amputation in patients with peripheral artery disease. Arterioscler Thromb Vasc Biol 2015;35(06):1532-1537

30 Noordzij MJ, Lefrandt JD, Loeffen EA, et al. Skin autofluorescence is increased in patients with carotid artery stenosis and peripheral artery disease. Int J Cardiovasc Imaging 2012;28(02): 431-438

31 Nin JW, Jorsal A, Ferreira I, et al. Higher plasma levels of advanced glycation end products are associated with incident cardiovascular disease and all-cause mortality in type 1 diabetes: a 12-year follow-up study. Diabetes Care 2011;34(02): 442-447

32 Lapolla A, Piarulli F, Sartore G, et al. Advanced glycation end products and antioxidant status in type 2 diabetic patients with and without peripheral artery disease. Diabetes Care 2007;30 (03):670-676

33 Malmstedt J, Frebelius S, Lengquist M, Jörneskog G, Wang J, Swedenborg J. The receptor for advanced glycation end products (Rage) and its ligands in plasma and infrainguinal bypass vein. Eur J Vasc Endovasc Surg 2016;51(04):579-586

34 Prasad A, Lane JR, Tsimikas S, et al. Plasma levels of advanced glycation end products are related to the clinical presentation and angiographic severity of symptomatic lower extremity peripheral arterial disease. Int J Angiol 2016;25(01):44-53

35 Tekabe Y, Kollaros M, Li C, Zhang G, Schmidt AM, Johnson L. Imaging receptor for advanced glycation end product expression in mouse model of hind limb ischemia. EJNMMI Res 2013;3(01): 37

36 Ritthaler U, Deng Y, Zhang Y, et al. Expression of receptors for advanced glycation end products in peripheral occlusive vascular disease. Am J Pathol 1995;146(03):688-694

$37 \mathrm{Kim}$ BH, Ko YG, Kim SH, et al. Suppression of receptor for advanced glycation end products improves angiogenic responses to ischemia in diabetic mouse hindlimb ischemia model. ISRN Vascular Medicine 2013:1-7
38 Falcone C, Bozzini S, Guasti L, et al. Soluble RAGE plasma levels in patients with coronary artery disease and peripheral artery disease. ScientificWorldJournal 2013;2013:584504

39 Bucala R, Makita Z, Vega G, et al. Modification of low density lipoprotein by advanced glycation end products contributes to the dyslipidemia of diabetes and renal insufficiency. Proc Natl Acad Sci U S A 1994;91(20):9441-9445

40 Sutton G, Pugh D, Dhaun N. Developments in the role of endothelin-1 in atherosclerosis: a potential therapeutic target? Am J Hypertens 2019;32(09):813-815

41 Chang JB, Chu NF, Syu JT, Hsieh AT, Hung YR. Advanced glycation end products (AGEs) in relation to atherosclerotic lipid profiles in middle-aged and elderly diabetic patients. Lipids Health Dis 2011;10:228

42 Brownlee M, Cerami A, Vlassara H. Advanced glycosylation end products in tissue and the biochemical basis of diabetic complications. N Engl J Med 1988;318(20):1315-1321

43 Brownlee M, Vlassara H, Cerami A. Nonenzymatic glycosylation products on collagen covalently trap low-density lipoprotein. Diabetes 1985;34(09):938-941

44 Brownlee M, Vlassara H, Kooney A, Ulrich P, Cerami A. Aminoguanidine prevents diabetes-induced arterial wall protein crosslinking. Science 1986;232(4758):1629-1632

45 Bucala R, Makita Z, Koschinsky T, Cerami A, Vlassara H. Lipid advanced glycosylation: pathway for lipid oxidation in vivo. Proc Natl Acad Sci U S A 1993;90(14):6434-6438

46 Bucala R, Cerami A, Vlassara H. Advanced glycation end products in diabetic complications. Diabetes Rev (Alex) 1995;3:258-268

47 Ren X, Ren L, Wei Q, Shao H, Chen L, Liu N. Advanced glycation end-products decreases expression of endothelial nitric oxide synthase through oxidative stress in human coronary artery endothelial cells. Cardiovasc Diabetol 2017;16(01):52

48 Bucala R, Tracey KJ, Cerami A. Advanced glycosylation products quench nitric oxide and mediate defective endothelium-dependent vasodilatation in experimental diabetes. J Clin Invest 1991; 87(02):432-438

49 Xu B, Chibber R, Ruggiero D, Kohner E, Ritter J, Ferro A. Impairment of vascular endothelial nitric oxide synthase activity by advanced glycation end products. FASEB J 2003;17(10):1289-1291

50 Rojas A, Romay S, González D, Herrera B, Delgado R, Otero K. Regulation of endothelial nitric oxide synthase expression by albumin-derived advanced glycosylation end products. Circ Res 2000;86(03):E50-E54

51 Goldin A, Beckman JA, Schmidt AM, Creager MA. Advanced glycation end products: sparking the development of diabetic vascular injury. Circulation 2006;114(06):597-605

52 Hogan M, Cerami A, Bucala R. Advanced glycosylation endproducts block the antiproliferative effect of nitric oxide. Role in the vascular and renal complications of diabetes mellitus. J Clin Invest 1992;90(03):1110-1115

53 Matsui T, Oda E, Higashimoto Y, Yamagishi S. Glyceraldehydederived pyridinium (GLAP) evokes oxidative stress and inflammatory and thrombogenic reactions in endothelial cells via the interaction with RAGE. Cardiovasc Diabetol 2015;14:1-10

54 Quehenberger P, Bierhaus A, Fasching P, et al. Endothelin 1 transcription is controlled by nuclear factor-kappaB in AGEstimulated cultured endothelial cells. Diabetes 2000;49(09): 1561-1570

55 Haberland ME, Fless GM, Scanu AM, Fogelman AM. Malondialdehyde modification of lipoprotein(a) produces avid uptake by human monocyte-macrophages. J Biol Chem 1992;267(06): 4143-4151

56 Makita T, Tanaka A, Numano F. Effect of glycated low density lipoprotein on smooth muscle cell proliferation. Int Angiol 1999; 18(04):331-334

57 Horiuchi S, Sakamoto Y, Sakai M. Scavenger receptors for oxidized and glycated proteins. Amino Acids 2003;25(3-4):283-292 
58 Brown BE, Dean RT, Davies MJ. Glycation of low-density lipoproteins by methylglyoxal and glycolaldehyde gives rise to the in vitro formation of lipid-laden cells. Diabetologia 2005;48(02): 361-369

59 Hofmann MA, Drury S, Fu C, et al. RAGE mediates a novel proinflammatory axis: a central cell surface receptor for $\mathrm{S100/}$ calgranulin polypeptides. Cell 1999;97(07):889-901

60 Basta G, Lazzerini G, Massaro M, et al. Advanced glycation end products activate endothelium through signal-transduction receptor RAGE: a mechanism for amplification of inflammatory responses. Circulation 2002;105(07):816-822

61 Siebenlist U, Franzoso G, Brown K. Structure, regulation and function of NF-K B. Annu Rev Cell Biol 1994;10:405-455

62 Anrather J, Racchumi G, Iadecola C. NF-kappaB regulates phagocytic NADPH oxidase by inducing the expression of gp91phox. J Biol Chem 2006;281(09):5657-5667

63 Kislinger $\mathrm{T}$, Tanji N, Wendt $\mathrm{T}$, et al. Receptor for advanced glycation end products mediates inflammation and enhanced expression of tissue factor in vasculature of diabetic apolipoprotein E-null mice. Arterioscler Thromb Vasc Biol 2001;21(06): 905-910

64 Matsui T, Yamagishi S, Ueda S, et al. Telmisartan, an angiotensin II type 1 receptor blocker, inhibits advanced glycation endproduct (AGE)-induced monocyte chemoattractant protein-1 expression in mesangial cells through downregulation of receptor for AGEs via peroxisome proliferator-activated receptorgamma activation. J Int Med Res 2007;35(04):482-489

65 Yamagishi S, Inagaki Y, Okamoto T, et al. Advanced glycation end product-induced apoptosis and overexpression of vascular endothelial growth factor and monocyte chemoattractant protein1 in human-cultured mesangial cells. J Biol Chem 2002;277(23): 20309-20315

$66 \mathrm{Gu} \mathrm{L}$, Hagiwara S, Fan Q et al. Role of receptor for advanced glycation end-products and signalling events in advanced glycation end-product-induced monocyte chemoattractant protein-1 expression in differentiated mouse podocytes. Nephrol Dial Transplant 2006;21(02):299-313

67 Sasaki T, Horiuchi S, Yamazaki M, Yui S. Induction of GM-CSF production of macrophages by advanced glycation end products of the Maillard reaction. Biosci Biotechnol Biochem 1999;63 (11):2011-2013

68 Kirstein M, Brett J, Radoff S, Ogawa S, Stern D, Vlassara H. Advanced protein glycosylation induces transendothelial human monocyte chemotaxis and secretion of platelet-derived growth factor: role in vascular disease of diabetes and aging. Proc Natl Acad Sci U S A 1990;87(22):9010-9014

69 Kirstein M, Aston C, Hintz R, Vlassara H. Receptor-specific induction of insulin-like growth factor I in human monocytes by advanced glycosylation end product-modified proteins. J Clin Invest 1992;90(02):439-446

70 Schmidt AM, Yan SD, Brett J, Mora R, Nowygrod R, Stern D. Regulation of human mononuclear phagocyte migration by cell surface-binding proteins for advanced glycation end products. J Clin Invest 1993;91(05):2155-2168

71 Miyata T, Inagi R, Iida $Y$, et al. Involvement of $\beta$ 2-microglobulin modified with advanced glycation end products in the pathogenesis of hemodialysis-associated amyloidosis. Induction of human monocyte chemotaxis and macrophage secretion of tumor necrosis factor- $\alpha$ and interleukin-1. J Clin Invest 1994;93(02):521-528

72 Sakata N, Meng J, Takebayashi S. Effects of advanced glycation end products on the proliferation and fibronectin production of smooth muscle cells. J Atheroscler Thromb 2000;7(03):169-176

73 Higashi T, Sano H, Saishoji T, et al. The receptor for advanced glycation end products mediates the chemotaxis of rabbit smooth muscle cells. Diabetes 1997;46(03):463-472

74 Wolf YG, Rasmussen LM, Ruoslahti E. Antibodies against transforming growth factor- $\beta 1$ suppress intimal hyperplasia in a rat model. J Clin Invest 1994;93(03):1172-1178
75 Steinberg D. Antioxidants and atherosclerosis. A current assessment. Circulation 1991;84(03):1420-1425

76 Aronson D, Rayfield EJ. How hyperglycemia promotes atherosclerosis: molecular mechanisms. Cardiovasc Diabetol 2002;1:1

77 Prasad K. The pathophysiology of atherosclerosis. In: Chang JB, ed. Textbook of Angiology. New York, NY: Springer; 2000:17-46

78 Nowak WN, Deng J, Ruan XZ, Xu Q. Reactive oxygen species generation and atherosclerosis. Arterioscler Thromb Vasc Biol 2017;37(05):e41-e52

79 Kattoor AJ, Pothineni NVK, Palagiri D, Mehta JL. Oxidative stress in atherosclerosis. Curr Atheroscler Rep 2017;19(11):42

80 Weisenberger J. Foods High in AGEs. Available at: http:// wwwdiabetesforecastorg/2014/11-nov/foods-high-inageshtml. Accessed 2014

81 Uribarri J, Woodruff S, Goodman S, et al. Advanced glycation end products in foods and a practical guide to their reduction in the diet. J Am Diet Assoc 2010;110(06):911-16.e12

82 Uribarri J, Cai W, Sandu O, Peppa M, Goldberg T, Vlassara H. Dietderived advanced glycation end products are major contributors to the body's AGE pool and induce inflammation in healthy subjects. Ann N Y Acad Sci 2005;1043:461-466

83 Prasad K, Dhar I, Caspar-Bell G. Role of advanced glycation end products and its receptors in the pathogenesis of cigarette smokeinduced cardiovascular disease. Int J Angiol 2015;24(02):75-80

84 Kondoh Y, Kawase M, Ohmori S. D-lactate concentrations in blood, urine and sweat before and after exercise. Eur J Appl Physiol Occup Physiol 1992;65(01):88-93

85 Salama ME, El-Damarawi MA, Salama AF. A comparison between the impact of two different exercise protocols on advanced glycation end products in type 2 diabetic rats. Life Sci J 2013; 10(03):860-869

86 Goon JA, Aini AH, Musalmah M, Anum MY, Nazaimoon WM, Ngah WZ. Effect of Tai Chi exercise on DNA damage, antioxidant enzymes, and oxidative stress in middle-age adults. J Phys Act Health 2009;6(01):43-54

87 Ramful D, Tarnus E, Rondeau P, Da Silva CR, Bahorun T, Bourdon E. Citrus fruit extracts reduce advanced glycation end products (AGEs)- and $\mathrm{H}_{2} \mathrm{O}_{2}$-induced oxidative stress in human adipocytes. J Agric Food Chem 2010;58(20):11119-11129

88 Liu W, Ma H, Frost L, Yuan T, Dain JA, Seeram NP. Pomegranate phenolics inhibit formation of advanced glycation endproducts by scavenging reactive carbonyl species. Food Funct 2014;5(11): 2996-3004

89 Hammes HP, Du X, Edelstein D, et al. Benfotiamine blocks three major pathways of hyperglycemic damage and prevents experimental diabetic retinopathy. Nat Med 2003;9(03):294-299

90 Metz TO, Alderson NL, Thorpe SR, Baynes JW. Pyridoxamine, an inhibitor of advanced glycation and lipoxidation reactions: a novel therapy for treatment of diabetic complications. Arch Biochem Biophys 2003;419(01):41-49

91 Subratty AH, Aukburally N, Jowaheer V, et al. Vitamin C and urea inhibit the formation of advanced glycation end products in vitro. Nutr Food Sci 2010;40(05):456-465

92 Salum E, Kals J, Kampus P, et al. Vitamin D reduces deposition of advanced glycation end-products in the aortic wall and systemic oxidative stress in diabetic rats. Diabetes Res Clin Pract 2013;100 (02):243-249

93 Baragetti I, Furiani S, Vettoretti S, et al. Role of vitamin E-coated membrane in reducing advanced glycation end products in hemodialysis patients: a pilot study. Blood Purif 2006;24(04): 369-376

94 Ghodsi R, Kheirouri S. Carnosine and advanced glycation end products: a systematic review. Amino Acids 2018;50(09): 1177-1186

95 Menini S, Iacobini C, Ricci C, et al. D-Carnosine octylester attenuates atherosclerosis and renal disease in ApoE null mice fed a Western diet through reduction of carbonyl stress and inflammation. Br J Pharmacol 2012;166(04):1344-1356 
96 Menini S, Iacobini C, Ricci C, Blasetti Fantauzzi C, Pugliese G. Protection from diabetes-induced atherosclerosis and renal disease by D-carnosine-octylester: effects of early vs late inhibition of advanced glycation end-products in Apoe-null mice. Diabetologia 2015;58(04):845-853

97 Prasanna G, Saraswathi NT. Linolenic acid prevents early and advanced glycation end-products (AGEs) modification of albumin. Int J Biol Macromol 2017;95:121-125

98 Thornalley PJ. Use of aminoguanidine (Pimagedine) to prevent the formation of advanced glycation end products. Arch Biochem Biophys 2003;419(01):31-40

99 Freedman BI, Wuerth JP, Cartwright K, et al. Design and baseline characteristics for the aminoguanidine clinical trial in overt Type 2 diabetic nephropathy (ACTION II). Control Clin Trials 1999;20 (05):493-510

100 Abdul HM, Butterfield DA. Involvement of PI3K/PKG/ERK1/2 signaling pathways in cortical neurons to trigger protection by cotreatment of acetyl-L-carnitine and alpha-lipoic acid against HNE-mediated oxidative stress and neurotoxicity: implications for Alzheimer's disease. Free Radic Biol Med 2007;42(03):371-384

101 Urios P, Grigorova-Borsos AM, Sternberg M. Aspirin inhibits the formation of pentosidine, a cross-linking advanced glycation end product, in collagen. Diabetes Res Clin Pract 2007;77(02):337-340

102 Beisswenger PJ, Howell SK, Touchette AD, Lal S, Szwergold BS. Metformin reduces systemic methylglyoxal levels in type 2 diabetes. Diabetes 1999;48(01):198-202

103 Rahbar S, Natarajan R, Yerneni K, Scott S, Gonzales N, Nadler JL. Evidence that pioglitazone, metformin and pentoxifylline are inhibitors of glycation. Clin Chim Acta 2000;301(1-2):65-77

104 Mizutani K, Ikeda K, Yamori Y. Resveratrol inhibits AGEs-induced proliferation and collagen synthesis activity in vascular smooth muscle cells from stroke-prone spontaneously hypertensive rats. Biochem Biophys Res Commun 2000;274(01):61-67

105 Tang Y, Chen A. Curcumin eliminates the effect of advanced glycation end-products (AGEs) on the divergent regulation of gene expression of receptors of AGEs by interrupting leptin signaling. Lab Invest 2014;94(05):503-516

106 Cuccurullo C, Iezzi A, Fazia ML, et al. Suppression of RAGE as a basis of simvastatin-dependent plaque stabilization in type 2 diabetes. Arterioscler Thromb Vasc Biol 2006;26(12):2716-2723

107 Xu L, Zang P, Feng B, Qian Q. Atorvastatin inhibits the expression of RAGE induced by advanced glycation end products on aortas in healthy Sprague-Dawley rats. Diabetol Metab Syndr 2014;6 (01):102

108 Nakamura K, Yamagishi S, Nakamura Y, et al. Telmisartan inhibits expression of a receptor for advanced glycation end products (RAGE) in angiotensin-II-exposed endothelial cells and decreases serum levels of soluble RAGE in patients with essential hypertension. Microvasc Res 2005;70(03):137-141

109 Fan Q, Liao J, Kobayashi M, et al. Candesartan reduced advanced glycation end-products accumulation and diminished nitrooxidative stress in type 2 diabetic KK/Ta mice. Nephrol Dial Transplant 2004;19(12):3012-3020

110 Yamagishi S, Takeuchi M. Nifedipine inhibits gene expression of receptor for advanced glycation end products (RAGE) in endothelial cells by suppressing reactive oxygen species generation. Drugs Exp Clin Res 2004;30(04):169-175

111 Marx N, Walcher D, Ivanova N, et al. Thiazolidinediones reduce endothelial expression of receptors for advanced glycation end products. Diabetes 2004;53(10):2662-2668

112 Lin J, Tang Y, Kang Q, Feng Y, Chen A. Curcumin inhibits gene expression of receptor for advanced glycation end-products (RAGE) in hepatic stellate cells in vitro by elevating PPARr activity and attenuating oxidative stress. Br J Pharmacol 2012; 166(08):2212-2227

113 Sabbagh MN, Agro A, Bell J, Aisen PS, Schweizer E, Galasko D. PF04494700 , an oral inhibitor of receptor for advanced glycation end products (RAGE), in Alzheimer disease. Alzheimer Dis Assoc Disord 2011;25(03):206-212

114 Bongarzone S, Savickas V, Luzi F, Gee AD. Targeting the receptor for advanced glycation endproducts (RAGE): a medicinal chemistry perspective. J Med Chem 2017;60(17):7213-7232

115 Burstein AH, Sabbagh M, Andrews R, Valcarce C, Dunn I, Altstiel L. Development of azeliragon, an oral small molecule antagonist of the receptor for advanced glycation endproducts, for the potential slowing of loss of cognition in mild Alzheimer's disease. J Prev Alzheimers Dis 2018;5(02):149-154

116 A phase 2 study evaluating the efficacy and safety of PF04494700 in mild to moderate Alzheimer's disease. Pfizer, Alzheimer's disease Cooperative Study (ADCS). Clinical trials.gov identifier: NCT00566397. Available at: http://clinicaltrials.gov/ct2/show/ NCToo566397. Accessed April 7, 2020

117 Mannervik B. Molecular enzymology of the glyoxalase system. Drug Metabol Drug Interact 2008;23(1-2):13-27

118 Xue M, Weickert MO, Qureshi S, et al. Improved glycemic control and vascular function in overweight and obese subjects by glyoxalase 1 inducer formulation. Diabetes 2016;65(08):2282-2294

119 Gangadhariah MH, Mailankot M, Reneker L, Nagaraj RH. Inhibition of methylglyoxal-mediated protein modification in glyoxalase I overexpressing mouse lenses. J Ophthalmol 2010;2010:274317

120 Miller AG, Smith DG, Bhat M, Nagaraj RH. Glyoxalase I is critical for human retinal capillary pericyte survival under hyperglycemic conditions. J Biol Chem 2006;281(17):11864-11871

121 Lu C, He JC, Cai W, Liu H, Zhu L, Vlassara H. Advanced glycation endproduct (AGE) receptor 1 is a negative regulator of the inflammatory response to AGE in mesangial cells. Proc Natl Acad Sci U S A 2004;101(32):11767-11772

122 Cai W, He JC, Zhu L, Lu C, Vlassara H. Advanced glycation end product (AGE) receptor 1 suppresses cell oxidant stress and activation signaling via EGF receptor. Proc Natl Acad Sci U S A 2006;103(37):13801-13806

123 Cai W, He JC, Zhu L, Chen X, Striker GE, Vlassara H. AGE-receptor1 counteracts cellular oxidant stress induced by AGEs via negative regulation of p66shc-dependent FKHRL1 phosphorylation. Am J Physiol Cell Physiol 2008;294(01):C145-C152

$124 \mathrm{He}$ CJ, Koschinsky T, Buenting C, Vlassara H. Presence of diabetic complications in type 1 diabetic patients correlates with low expression of mononuclear cell AGE-receptor-1 and elevated serum AGE. Mol Med 2001;7(03):159-168

125 Nozue T, Yamagishi S-i, Takeuchi M, et al. Effect of statins on the serum soluble form of receptor for advanced glycation endproducts and its association with coronary atherosclerosis in patients with angina pectoris. IJC Metab Endocr 2014;4:47-52

126 Tam HL, Shiu SW, Wong Y, Chow WS, Betteridge DJ, Tan KC. Effects of atorvastatin on serum soluble receptors for advanced glycation end-products in type 2 diabetes. Atherosclerosis 2010; 209(01):173-177

127 Quade-Lyssy P, Kanarek AM, Baiersdörfer M, Postina R, Kojro E. Statins stimulate the production of a soluble form of the receptor for advanced glycation end products. J Lipid Res 2013;54(11):3052-3061

128 Forbes JM, Thorpe SR, Thallas-Bonke V, et al. Modulation of soluble receptor for advanced glycation end products by angiotensin-converting enzyme-1 inhibition in diabetic nephropathy. J Am Soc Nephrol 2005;16(08):2363-2372

129 Tan KCB, Chow WS, Tso AWK, et al. Thiazolidinedione increases serum soluble receptor for advanced glycation end-products in type 2 diabetes. Diabetologia 2007;50(09):1819-1825

130 Irani M, Minkoff H, Seifer DB, Merhi Z. Vitamin D increases serum levels of the soluble receptor for advanced glycation end products in women with PCOS. J Clin Endocrinol Metab 2014;99(05): E886-E890

131 Park L, Raman KG, Lee KJ, et al. Suppression of accelerated diabetic atherosclerosis by the soluble receptor for advanced glycation endproducts. Nat Med 1998;4(09):1025-1031 
132 Tang SC, Wang YC, Li YI, et al. Functional role of soluble receptor for advanced glycation end products in stroke. Arterioscler Thromb Vasc Biol 2013;33(03):585-594

133 Yang X, Li Y, Li Y, et al. Oxidative stress-mediated atherosclerosis: mechanisms and therapies. Front Physiol 2017;8:600

134 Prasad K. Reduction of serum cholesterol and hypercholesterolemic atherosclerosis in rabbits by secoisolariciresinol diglucoside isolated from flaxseed. Circulation 1999;99(10):1355-1362

135 Prasad K, Kalra J, Lee P. Oxygen free radicals as a mechanism of hypercholesterolemic athetrosclerosis: effects of probucol. Int J Angiol 1994;3:100-112

136 Azen SP, Qian D, Mack WJ, et al. Effect of supplementary antioxidant vitamin intake on carotid arterial wall intima-media thickness in a controlled clinical trial of cholesterol lowering. Circulation 1996;94(10):2369-2372

137 Gale CR, Ashurst HE, Powers HJ, Martyn CN. Antioxidant vitamin status and carotid atherosclerosis in the elderly. Am J Clin Nutr 2001;74(03):402-408

138 Prasad K, Kalra J. Oxygen free radicals and hypercholesterolemic atherosclerosis: effect of vitamin E. Am Heart J 1993;125(04): 958-973

139 Meydani M, Kwan P, Band M, et al. Long-term vitamin E supplementation reduces atherosclerosis and mortality in Ldlr-/- mice, but not when fed Western style diet. Atherosclerosis 2014;233 (01):196-205

140 Saboori S, Shab-Bidar S, Speakman JR, Yousefi Rad E, Djafarian K. Effect of vitamin E supplementation on serum C-reactive protein level: a meta-analysis of randomized controlled trials. Eur J Clin Nutr 2015;69(08):867-873

141 Myung SK, Ju W, Cho B, et al; Korean Meta-Analysis Study Group. Efficacy of vitamin and antioxidant supplements in prevention of cardiovascular disease: systematic review and meta-analysis of randomised controlled trials. BMJ 2013;346:f10

142 Niki E. Interaction of ascorbate and alpha-tocopherol. Ann N Y Acad Sci 1987;498:186-199

143 Mashima R, Witting PK, Stocker R. Oxidants and antioxidants in atherosclerosis. Curr Opin Lipidol 2001;12(04):411-418

144 Witting PK, Pettersson K, Letters J, Stocker R. Anti-atherogenic effect of coenzyme Q10 in apolipoprotein E gene knockout mice. Free Radic Biol Med 2000;29(3-4):295-305

145 Heinecke JW. Oxidants and antioxidants in the pathogenesis of atherosclerosis: implications for the oxidized low density lipoprotein hypothesis. Atherosclerosis 1998;141(01):1-15

146 Stocker R. Dietary and pharmacological antioxidants in atherosclerosis. Curr Opin Lipidol 1999;10(06):589-597

147 Blake GJ, Ridker PM. Novel clinical markers of vascular wall inflammation. Circ Res 2001;89(09):763-771

148 Noguchi N, Niki E. Phenolic antioxidants: a rationale for design and evaluation of novel antioxidant drug for atherosclerosis. Free Radic Biol Med 2000;28(10):1538-1546

149 Prasad K, Mantha SV, Kalra J, Lee P. Prevention of hypercholesterolemic atherosclerosis by garlic, an antioxidant. J Cardiovasc Pharmacol Ther 1997;2(04):309-320

150 Cooke JP, Dzau VJ. Derangements of the nitric oxide synthase pathway, L-arginine, and cardiovascular diseases. Circulation 1997;96(02):379-382
151 Harrison DG. Cellular and molecular mechanisms of endothelial cell dysfunction. J Clin Invest 1997;100(09):2153-2157

152 Persson F, Rossing P, Hovind P, et al. Endothelial dysfunction and inflammation predict development of diabetic nephropathy in the Irbesartan in Patients with Type 2 Diabetes and Microalbuminuria (IRMA 2) study. Scand J Clin Lab Invest 2008;68 (08):731-738

153 Khera AV, Cuchel M, de la Llera-Moya M, et al. Cholesterol efflux capacity, high-density lipoprotein function, and atherosclerosis. N Engl J Med 2011;364(02):127-135

154 Wautier JL, Guillausseau PJ. Advanced glycation end products, their receptors and diabetic angiopathy. Diabetes Metab 2001;27 (5 Pt 1):535-542

155 Nakamura Y, Horii Y, Nishino T, et al. Immunohistochemical localization of advanced glycosylation end products in coronary atheroma and cardiac tissue in diabetes mellitus. Am J Pathol 1993;143(06):1649-1656

156 Koyama H, Yamamoto H, Nishizawa Y. RAGE and soluble RAGE: potential therapeutic targets for cardiovascular diseases. Mol Med 2007;13(11-12):625-635

157 Tan KC, Shiu SW, Chow WS, Leng L, Bucala R, Betteridge DJ. Association between serum levels of soluble receptor for advanced glycation end products and circulating advanced glycation end products in type 2 diabetes. Diabetologia 2006;49(11): 2756-2762

158 Challier M, Jacqueminet S, Benabdesselam O, Grimaldi A, Beaudeux JL. Increased serum concentrations of soluble receptor for advanced glycation endproducts in patients with type 1 diabetes. Clin Chem 2005;51(09):1749-1750

159 Lin RY, Choudhury RP, Cai W, et al. Dietary glycotoxins promote diabetic atherosclerosis in apolipoprotein E-deficient mice. Atherosclerosis 2003;168(02):213-220

160 Boor P, Celec P, Behuliak M, et al. Regular moderate exercise reduces advanced glycation and ameliorates early diabetic nephropathy in obese Zucker rats. Metabolism 2009;58(11):1669-1677

161 Couppé C, Svensson RB, Grosset JF, et al. Life-long endurance running is associated with reduced glycation and mechanical stress in connective tissue. Age (Dordr) 2014;36(04):9665

162 Magalhaes PM, Appell HJ, Durate JA. Involvement of advanced glycation end products in the pathogenesis of diabetic complications: protective role of regular physical activity. Eur Rev Aging Phys Act 2008;5:17-29

163 Stirban A, Negrean M, Stratmann B, et al. Benfotiamine prevents macro- and microvascular endothelial dysfunction and oxidative stress following a meal rich in advanced glycation end products in individuals with type 2 diabetes. Diabetes Care 2006;29(09): 2064-2071

164 Dutta A, Dutta SK. Vitamin E and its role in the prevention of atherosclerosis and carcinogenesis: a review. J Am Coll Nutr 2003;22(04):258-268

165 Salonen RM, Nyyssönen K, Kaikkonen J, et al; Antioxidant Supplementation in Atherosclerosis Prevention Study. Six-year effect of combined vitamin $C$ and $E$ supplementation on atherosclerotic progression: the Antioxidant Supplementation in Atherosclerosis Prevention (ASAP) study. Circulation 2003;107(07): 947-953 